По-третє, фіксують складний характер цього соціально-педагогічного явища, як у його визначенні, так і у використанні й оцінюванні результатів. Подальшу свою роботу ми вбачаємо в розробленні завдань із педагогічної практики, яка сприятиме підвищенню професійної компетентності майбутнього вчителя.

\title{
Література
}

1. Митина Л. М. Психология профессионального развития учителя / Лариса Максимовна Митина. - М. : Московский психолого-социальный институт; Издательство «Флинта», 1998. - $180 \mathrm{c}$.

2. Равен Дж. Компетентность в современном обществе: выявление, развитие и реализация / Дж. Равен. - М. : Когито-Центр, 2002. - 257c.

3. Сластенин В. А. Профессионализм педагога: акмеологический контекст /В. А. Сластенин // Педагогическое образование и наука. - 2002. - №4. - С. 1-9.

4. Словарь иностранных слов / под ред. И.В. Лехина, С.М. Локшиной и др.; [изд. 6-е]. - М. : Советская энциклопедия, 1964. - 784 с.

5. Шаталов А. А. Мониторинг и диагностика качества образования: [монография]/ Шаталов А. А., Афанасьев В. В., Афанасьева И. В., Гвоздева Е. А., Пичугина А. М. - М. : НИИ школьных технологий, 2008. - 322 с.

Стаття надійшла до редакції 23.05.2012 p.

УДК. 37.043 .048

Н. В. Берестецька, кандидат пед.наук, доцент, Начіональна академія Державної прикордонної служби України імені Богдана Хмельнииького

\section{НОВІ ПІДХОДИ ДО ОРГАНІЗАЦІЇ САМОСТІЙНОЇ ПІДГОТОВКИ ПЕРСОНАЛУ ДЕРЖАВНОЇ ПРИКОРДОННОЇ СЛУЖБИ УКРАЇНИ}

\begin{abstract}
Берестецька Н. В. Нові підходи до організащії самостійної підготовки персоналу Державної прикордонної служби Украӥни.

На трунті проведеного теоретичного аналізу наукових джерел та нормативних документів проаналізовано організацію самостійної підготовки персоналу Державної прикордонної служби України, вивчено нові підходи до ї̈ ефективного використання в підрозділах охорони кордону, а також запропоновано методичні рекомендації щодо ї̈ вдосконалення. Особливу увагу приділено вивченню іноземної мови персоналом ДПСУ під час самостійної підготовки та розроблення індивідуальних завдань для прикордонників.

Ключові слова: самостійна підготовка, персонал, Державна прикордонна служба України, індивідуальне завдання.

Берестечкая Н. В. Новые подходы к организации самостоятельной подготовки персонала Государственной пограничной службы Украины.

На основе проведенного теоретического анализа научных источников и нормативных документов проанализировано организаиию самостоятельной подготовки персонала Государственной пограничной службы Украины, изучено новые подходы к ее эффективному использованию в подразделениях охраны гранищы, а также предложены методические рекомендации $\kappa$ ее улучшению. Особое внимание уделено изучению иностранного языка персоналом ГПСУ во время самостоятельной подготовки та разработке индивидуальных заданий для пограничников.
\end{abstract}

Ключевые слова: самостоятельная подготовка, персонал, Государственная пограничная служба Украины, индивидуальные задания. 
Berestetska N. New approaches towards organization of independent work of personnel of the State Border Guard Service of Ukraine.

On the basis of theoretical analysis of scientific sources and official documents the organization of independent work of personnel of the State Border Guard Service of Ukraine has been analyzed; new approaches of its effective implementation within the border units have been examined; methodical recommendations concerning its improvement have been offered. The main attention has been drawn towards foreign language learning by the personnel of the State Border Guard Service of Ukraine during independent work and development of individual tasks for borderguards as well.

Key words: independent work, personnel, State Border Guard Service of Ukraine, individual task.

Постановка проблеми. У сучасних умовах розвиток Державної прикордонної служби України (ДПСУ) окреслюється в загальному контексті європейської інтеграції 3 орієнтацією на сучасні підходи до охорони державного кордону, у тому числі й до професійної підготовки персоналу. Не слід нівелювати того факту, що життєвий цикл сучасних технологій, у тому числі i технологій пов'язаних із процесами охорони державного кордону, постає меншим ніж термін професійної діяльності фахівця. За таких умов визначальним у системі професійної підготовки персоналу ДПСУ стає формування здатності прикордонника перебудовувати систему власної професійної діяльності відповідно до службових потреб [6].

Зауважимо, що система підготовки персоналу в межах певного курсу досить інертна - навчальний матеріал, який був вивчений на початку навчання, у кінці терміна навчання або уже в найближчий після його завершення час може втратити актуальність, а значний часовий проміжок може призвести до його деавтоматизації. Тому мета кожного фахівця полягає не лише в засвоєнні знань під час навчального курсу та межах його наповнюваності, а і в подальшому інтелектуальному розвитку, у вмінні їх самостійно сприймати і засвоювати професійні знання, необхідність яких виникає в процесі професійної діяльності. За умови готовності персоналу до самостійного навчання можливим $є$ підтримання та підвищення його кваліфікації в системі професійної підготовки, у тому числі в системі самостійної підготовки. У цьому і полягає актуальність проблеми.

Аналіз останніх досліджень та публікацій. Здійснений аналіз [1-9] засвідчує, що самостійна підготовка посідає важливе місце в системі професійної підготовки майбутнього спеціаліста. Проблему самостійної роботи, дистанційної освіти досліджували С. Псьол, Л. Цвяк. Проте особливості організації самостійної підготовки персоналу ДПСУ потребує детального вивчення та розроблення методичних рекомендацій щодо ії вдосконалення.

Мета статті - проаналізувати організацію самостійної підготовки персоналу ДПСУ, а також запропонувати методичні рекомендації щодо іii вдосконалення.

Виклад основного матеріалу. Модернізація системи професійної підготовки в ДПСУ відбувається під упливом європейських ініціатив, інтеграційних процесів сучасного суспільства тощо. Такі тенденції зумовлюють необхідність підготовки фахівців ДПСУ європейського рівня, що відповідають вимогам та викликам сучасного світу. 
В основу підготовки персоналу покладено принцип: «Кожен співробітник Держприкордонслужби персонально відповідає за рівень своєї професійної майстерності та якість виконання обов'язків за посадою». Керівники усіх рівнів повинні забезпечити підготовку підпорядкованого персоналу на рівні, який забезпечить його готовність до успішного виконання завдань за призначенням, та створити належні умови підпорядкованому персоналу для самостійної підготовки [4].

Одним із напрямків вдосконалення системи професійної підготовки прикордонників $\epsilon$ індивідуалізація їх підготовки, запровадження цілісної системи формування готовності до виконання службових завдань за індивідуальними навчальними планами, а також організація самостійної та індивідуальної роботи модераторів (слухачів).

Для підвищення якості професійної підготовки прикордонників необхідна раціональна та ефективна організація самостійної роботи у підрозділах ДПСУ. Так, самостійна робота - основа будь-якої навчальної діяльності, форма організації навчання та професійної підготовки, засіб оволодіння глибокими знаннями та навичками. У сучасних умовах розвитку прикордонного відомства України залишається необхідність вдосконалення організації самостійної підготовки, надання ій найбільш системного та конкретного характеру, нормативності та іiї наповнюваності.

Творча, наближена до наукового осмислення, робота можлива лише як результат організації самостійної підготовки з обов'язковою присутністю в ній цілепокладання та формування готовності до професійної діяльності за допомогою ефективних технологічних систем самостійної підготовки. Крім того, робота має бути індивідуалізованою 3 урахуванням рівня творчих можливостей слухача, його інтересів, службових обов'язків тощо. Самостійна робота передбачає створення умов для реалізації потенціалу слухача через індивідуально-спрямований розвиток його здібностей [1].

Отже, самостійна робота є важливою складовою процесу професійної підготовки та основним засобом оволодіння професійними заннями та навичками у час, вільний від занять чи виконання службових завдань. Проводиться задля закріплення й поглиблення знань, умінь i навичок, набутих під час навчальних занять; підготовки до подальших занять; засвоєння навчального матеріалу, який передбачено робочою навчальною програмою для самостійного вивчення; формування культури розумової праці, самостійності й ініціативи у пошуку та набутті знань.

Самостійна робота слухачів може передбачати:опрацювання теоретичних основ прослуханого лекційного матеріалу, вивчення окремих тем або питань, що передбачені для самостійного опрацювання, підготовка до виступу 3 заданої теми, переклад іноземних текстів встановлених обсягів, розв'язання і письмове оформлення робіт творчого характеру, підготовка конспектів наукових текстів, виконання домашніх завдань, підготовка до контрольних заходів.

Усі пропоновані світові та національні стандарти в основу навчання ставлять самостійну роботу того, хто навчається. На цьому принципі 
грунтуються i новітні технології навчання. Самостійна робота має складатися 3 планової самостійної підготовки; самостійної роботи за розкладом навчальних занять та у вільний від планових заходів час.

Час, відведений для самостійної (індивідуальної) підготовки, регламентується нормативними документами професійної підготовки та розпорядженнями керівниками підрозділів. Самостійна підготовка організується та забезпечується командирами підрозділів. Методичне керівництво самостійною підготовкою здійснюють мульиплікатори. Самостійна підготовка проводиться відповідно до розпорядку дня.

Самостійна підготовка модераторів забезпечується всіма навчальнометодичними засобами, необхідними для виконання конкретних завдань чи вивчення окремою теми: підручниками, навчальними та методичними посібниками, конспектами лекцій, інтерактивними навчально-методичними комплексами дисциплін, електронно-обчислювальною технікою тощо. Слухачам також рекомендується для самостійного опрацювання відповідна література та періодичні видання. Методичне забезпечення самостійної підготовки повинне передбачати й засоби самоконтролю (тести тощо).

Досліджуючи функції самостійної роботи, П. Підкасистий дійшов висновку, що вона виконує «роль специфічного педагогічного засобу організації і керування самостійною діяльністю студента в навчальному процесі» [5, с. 8-9]. С. Трубачова вважає, що процес самостійного пізнання є результатом мислиннєвої діяльності, його можна розглядати як активну цілеспрямовану діяльність, під час якої здійснюється перероблення вже відомої та щойно сприйнятої інформації [8].

Науковець П. Підкасистий виокремлює такі типи самостійної роботи: самостійна робота за зразком; реконструктивна самостійна робота; самостійна робота варіативного типу; творча самостійна робота [5]. Процес самостійної підготовки $є$ невід'ємним складником загального процесу професійної підготовки. Отже, його теж стосуються такі характеристики функціонування процесу професійної підготовки, як загальна цілеспрямованість, послідовність зміни цілей та завдань.

Суб'єкти самостійної підготовки є однією 3 характеристик цього процесу. Керівництво підрозділу ДПСУ є суб’єктом, який визначає цілі, ставить завдання та реалізує на місці служби відомчі вимоги щодо професійної підготовки фахівця та його подальшого вдосконалення. Зазначена участь носить попередній характер до безпосереднього процесу самостійної підготовки прикордонника, але є фундаментальною.

Іншим суб'єктом, який визначає цілі процесу самостійної підготовки, є мультиплікатор. У своєму цілепокладанні він ураховує цілі, що йдуть від керівництва підрозділу, зумовленими особливостями службової діяльності. Наступним суб'єктом визначення цілей та повноцінним учасником процесу організації самостійної підготовки ДПСУ $\epsilon$ слухач. Він завжди має формулювати для себе ціль, визначену поточним службовим завданням та має чітко усвідомлювати мету свого подальшого професійного розвитку. 
А. Кучерявий [2], аналізуючи суб'єктні аспекти організації самостійної підготовки у їхній сукупності та послідовності, вважає, що вони утворюють певну структуру, яка має таке схематичне відображення. (Рис. 1).

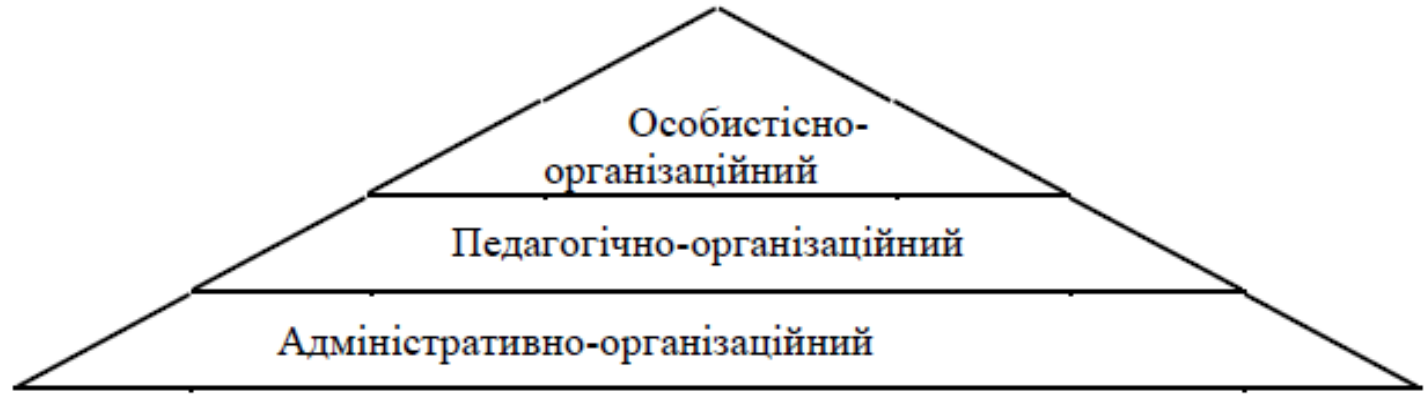

Рис. 1. Умови організаиії самостійної підготовки

Розглянемо докладніше кожен рівень схеми (Рис. 1). Так, елементи адміністративно-організаційного рівня підпорядковуються певній загальній меті. Саме тут можна говорити про реалізацію загальних потреб ДПСУ, а також персоналу ДПСУ для реалізації службових завдань. На цьому рівні відбуваються такі дії: постановка завдань в межах прикордонного відомства; відпрацювання концепції професійної підготовки персоналу ДПСУ на основі передових педагогічних ідей та інновацій; розроблення та затвердження нормативних документів щодо самостійної підготовки; призначення відповідальних осіб за проведення самостійної підготовки; ознайомлення персоналу ДПСУ з особливостями проведення самостійної підготовки та їх орієнтування на раціональне використання часу; підготовка керівників самостійної підготовки; опрацювання методичних рекомендацій, що стосуються самостійної підготовки.

Педагогічно-організаційний рівень стосується організації самостійної підготовки в межах підрозділу та його організаційно-методичного забезпечення. Цей рівень містить такі аспекти: розроблення та затвердження програми самостійної підготовки в підрозділі; відпрацювання графіку проведення самостійної підготовки в підрозділі; підготовка переліку рекомендованої літератури для проведення самостійної підготовки; розроблення спеціальних завдань; організація контролю за виконанням завдань; проведення бесід щодо мотивації персоналу ДПСУ до ефективної самостійної підготовки; організація консультацій для слухачів; відпрацювання документів щодо організації самостійної підготовки.

Особистісно-організаційний рівень спрямований на персональні цілі суб'єктів самостійної підготовки, а саме: мотиваційний рівень; службовий графік слухачів відповідно до виконання ними завдань, пов'язаних 3 основною професійною діяльністю; рівень та обсяг завдань, запропонованих для самостійної підготовки; забезпеченість літературою; наявність технічних засобів; індивідуальні психологічні якості.

Дехто 3 дослідників ідентифікує самостійну роботу 3 внутрішньою психічною діяльністю слухачів, що дає підстави говорити про два ряди ознак зовнішньоорганізаційні і внутрішньопсихічні. Перші полягають у 
можливості одержати потрібну допомогу від керівника (мультиплікатора), другі - у виникненні особливого виду діяльності. Ми вважаємо, що самостійна робота - це особливого роду діяльність, що характеризується оптимальною напруженістю й виникає під час виконання завдань, що вимагають вищого рівня, ніж наявний фонд знань і операцій.

Так, під час самостійної підготовки навчальна діяльність відбувається за схемою рівня залучення суб'єктів самостійної підготовки (Рис. 2).

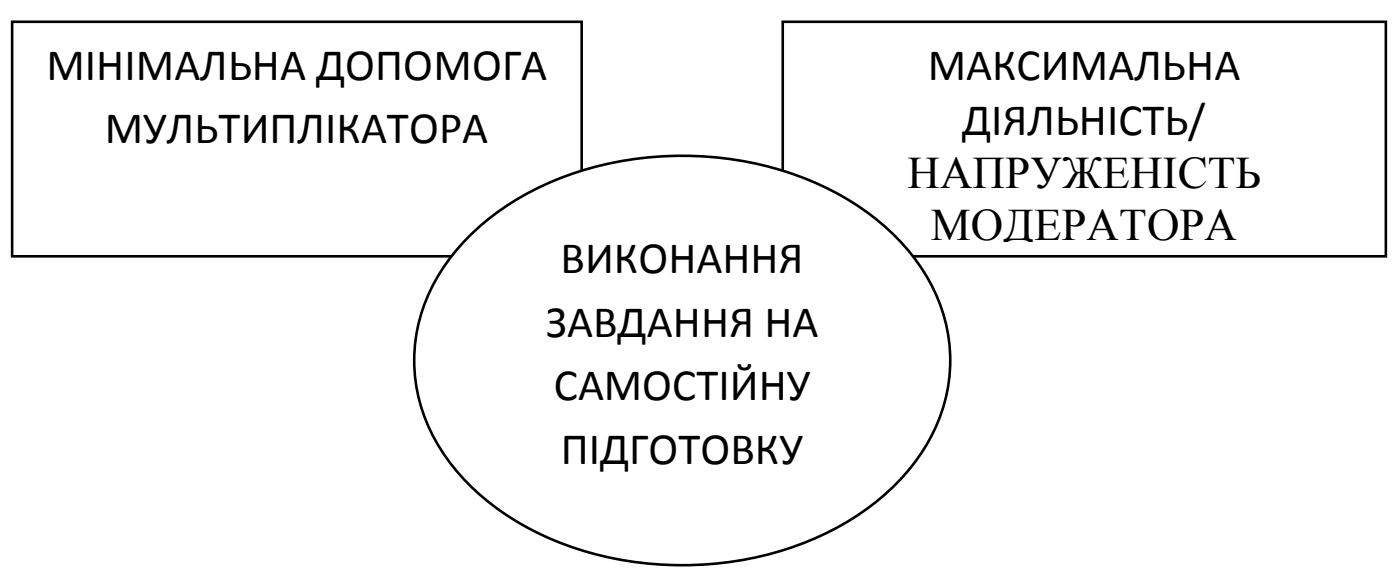

Рис. 2. Схема залучення суб'єктів до самостійної підготовки

Завдяки цій схемі можна пояснити взаємини суб'єктів в системі самостійної підготовки, а також вдосконалити рівні пізнавальної самостійності модератора, які диференціюються залежно від складності розв'язуваного завдання на основі заданого фонду знань операцій. Наявні недостатній, потрібний i надлишковий фонди. За умов максимальної психологічної та інтелектуальної напруженості процес навчання стає успішним, активізується розвивальна функція, збільшується існуючий фонд наявних знань. Це означає, що завдання розв'язуються позитивно, завдання на самостійну підготовку виконуються з позитивними результатами.

Мінімальна допомога полягає в тому, що мультиплікатор тільки ставить мету. Максимальна допомога передбачає, що висувається навчальна мета i розкриваються засоби іiі досягнення у вигляді деталізованої алгоритмічної інструкції. Мінімальне напруження буде там, де діяльність має репродуктивний характер, а максимальне - там, де внутрішня діяльність слухача наближається до творчого процесу.Міра допомоги визначається кількістю й характером опор: підказкою відповіді на запитання тощо.

Мiра напруженості також залежить від таких чинників: характеру та важливості завдання, наявності внутрішніх передумов для успішного його виконання, від суми знань слухача, бажання, мотивації, наявності об'єктивних чинників (місце, час, література, програмне забезпечення, тощо).

Відповідно до Наказу Адміністрації ДПСУ № 900 від 23. 11. 2011 року «Про підготовку персоналу Державної прикордонної служби у 2012 році» основні зусилля поточної підготовки персоналу зосереджено на підтриманні та розвитку професійних знань і вмінь, отриманих у процесі базової 
підготовки, що забезпечуватиме спроможність персоналу виконувати обов'язки за посадовим призначенням [4].

Поточна підготовка персоналу всіх категорій здійснюється безперервно протягом календарного року. Основними формами поточної підготовки персоналу вважається комплексні практичні заняття, практичні заняття, тренування, тренінги, безпосередня підготовка до служби, інформування, підготовка на зборах, під час проведення курсів мультиплікації. Важливе місце 3-поміж таким форм належить самостійній підготовці. Зважаючи на це, самостійна підготовка планується в межах поточної підготовки. Самостійна підготовка персоналу проводиться - не менше двох годин щотижня.

Начальник відділу прикордонної служби визначає зміст комплексного практичного заняття, враховуючи особливості оперативно-службової діяльності на ділянці відповідальності, рівень укомплектованості та рівень підготовленості підлеглих, використовуючи методичний матеріал тематичного плану.

Нормативними документами обгрунтовано пріоритетне завдання системи підвищення кваліфікації персоналу у 2012 році, а саме сформувати готовність персоналу до виконання завдань, пов'язаних із забезпеченням проведення в Україні фінальної частини чемпіонату Свропи 2012 року 3 футболу [4]. Зважаючи на це, варто додати до системи професійної підготовки персоналу ДПСУ самостійну підготовку з іноземної мови (англійської).

Зміст навчального матеріалу спрямований на забезпечення персоналу відділів прикордонної служби необхідними знаннями розмовної лексики та професійної термінології, основами фонетики та граматики для спілкування 3 іноземцями під час перевірки документів, а також для виконання службових завдань засобами іноземної мови. Крім того, слухачі опановують навички ведення бесіди в межах професійної діяльності, вчаться сприймати англійську на слух та реагувати на мову співрозмовника.

Проте тестування та опитування персоналу ДПСУ свідчить про те, що 3 часом спостерігається деавтоматизація здобутих знань, знижується рівень мовних навичок, зменшується запас професійної лексики. Для усунення негативних явищ варто враховувати наступні рекомендації: врахувати години для іншомовної підготовки в системі професійної підготовки, визначити спеціальне місця для самостійної підготовки 3 іноземної мов, вибрати необхідні форми та види самостійної підготовки, відпрацювати картку самостійної підготовки модератора, встановити графік проведення консультацій та індивідуальних завдань, використовувати технічні засоби навчання, за можливості створювати мовне середовище, заохочувати до проведення власних досліджень, ураховувати принципи диференціації й індивідуалізації, спланувати ведення робочого зошита слухача.

Висновки та перспективи подалыших досліджень. Самостійна підготовка є важливою частиною професійної підготовки персоналу ДПСУ та спрямована на вдосконалення професійного рівня фахівця 3 охорони державного кордону України. Проте, варто зважати, що правильна організація впливає на ефективність проведення самостійної підготовки, 
якісне виконання індивідуальних завдань, а також формування готовності прикордонника до виконання службових завдань. У подальшому планується дослідити ефективні методи та педагогічні прийоми організації самостійної підготовки, а також проаналізувати чинники, які впливають на діяльність слухачів під час годин самостійної підготовки.

\section{Література}

1. Застосування Європейської кредитно-трансферної системи у навчальному процесу [Електронний ресурс]. - Режим доступу: http:/ / www. nbuv. gov. Ua / portal / soc_gum / pspo /2011_33_1/ Kucheryavuy. pdf

2. Кучерявий А. О. Суб’єктно-діяльнісні особливості процесу організації самостійної навчальної діяльності в юридичних навчальних закладах / А. О.Кучерявий // Проблеми сучасної педагогічної освіти: педагогіка і психологія: [зб. наук. праць]. - № 33. - 2011. - Режим доступу: http:// www. nbuv. gov. Ua / portal / soc_gum / pspo /2011_33_1 / Kucheryavuy. pdf

3. Наказ Голови ДПСУ «Про організацію мовної підготовки персоналу Державної прикордонної служби України до проведення в Україні Євро-2012» від 11. 02.2011 року № 90.

4. Наказ Адміністрації ДПСУ № 900 від 23. 11. 2011 року «Про підготовку персоналу Державної прикордонної служби у 2012 році».

5. Пидкасистый П. И. Организация учебно-познавательной деятельности студентов : [учеб. пособие] / П. И. Пидкасистый. - М. : Педаг. общ-во России, 2004. - 112c.

6. Псьол С. В. Дистанційне навчання в системі професійної підготовки прикордонників: досвід і перспективи розвитку / С. В. Псьол, Л. В. Цвяк [Електронний peсурс] // Збірник наукових праць. Серія: Психолого-педагогічні науки. - Хмельницький : Вид-во НАДПСУ. - № 56. - 2010. - Режим доступу: http: // www. nbuv. gov. Ua /portal / soc_gum / znpnapv_ppn / 2010_56 / 10 psvdpr.pdf

7. Солдатенко М.М. Теорія і практика самостійної пізнавальної діяльності : [монографія] / М. М. Солдатенко. - К. : Видавництво НПУ імені М. П. Драгоманова, 2006. - 198 с.

8. Трубачова С. Роль методів самостійного набуття знань в організації пізнавальної діяльності учнів / С. Трубачова // Рідна школа. - № 1. - 2001. - С. 39-41.

9. Яворська Г. Х. Соціально-професійна зрілість курсантів вищих навчальних закладів освіти МВС : [монографія] / Г. Х. Яворська. - Одеса : ПЛАСКЕ ЗАТ, 2005. - 408 с.

Стаття надійшла до редакції 15.05.2012 p.

\section{ПРОБЛЕМИ АДАПТАЦЇ̈ СТУДЕНТІВ-ПЕРШОКУРСНИКІВ ДО НАВЧАННЯ У ВНЗ}

Балахтар В. В. Проблеми адаптачії студентів-першокурсників до навчання у ВНЗ.

У статті досліджено проблему адаптації студентської молоді, охарактеризовано найбільш вагомі чинники, зокрема стан адаптованості студентів-першокурсників до умов навчання у ВНЗ.

Ключові слова: адаптаиія, студент-першокурсник, особистість, група, пристосування, взаємодія.

Балахтар В. В. Проблемы адаптачии студентов первокурсников к обучению в вузе.

В статье исследована проблема адаптации студенческой молодежи, охарактеризованы наиболее существенные показатели, в том числе уровень адаптации студентов-первокурсников в условиях обучения в вузе.

Ключевые слова: адаптация, студент-первокурсник, личность, группа, приспособление, взаимодействие. 